\title{
Investigation of Primary School Teachers' Conflict Resolution Skills in Terms of Different Variables ${ }^{1}$
}

\author{
Hatice Vatansever Bayraktar ${ }^{1}$, Kamile Özge Yilmaz ${ }^{1}$ \\ ${ }^{1}$ Education Faculty, İstanbul Sabahattin Zaim University, Turkey \\ Correspondence: Hatice Vatansever Bayraktar, Education Faculty, İstanbul Sabahattin Zaim University, Turkey.
}

Received: July 15, 2016 Accepted: August 3, $2016 \quad$ Online Published: August 16, 2016

doi:10.11114/jets.v4i9.1741 URL: http://dx.doi.org/10.11114/jets.v4i9.1741

\begin{abstract}
In this study, it is aimed to determine the level of conflict resolution skills of primary school teachers and whether they vary by different variables. The study was organised in accordance with the scanning model. The universe of the study consists of primary school teachers working at 14 primary schools, two from each of the seven geographical regions. The sample group consists of 191 primary school teachers that were randomly selected from schools that make up the universe.

The "Conflict Resolution Skills" scale that was developed by Rahim in order to determine conflict resolution skills and adapted into Turkish by Gümüşeli (2001) was used in this study.

As a result of this study, it was found out that the conflict resolution skills of primary school teachers are at the medium level. It is seen that primary school teachers generally prefer the Integrating Approach as a general way of conflict resolution. Upon examining the relations of teachers' conflict resolution skills with their demographic properties, a significant difference was found between the independent variables of age and duration of service and compromising approach. It was concluded that teachers between the ages of 34 and 39 tend to use the compromising approach more than teachers in other age groups, while teachers with a period of service of 21 and more tend to use the compromising approach more than teachers working at other durations of service. Conflict resolution skills of primary school teachers do not vary significantly by the variables of marital status, gender, educational status, geographical region and the province they work.
\end{abstract}

Keywords: conflict, conflict management, demographic properties

\section{Introduction}

"It is quite hard to make an extensive and general definition of conflict, which occurs at very different areas and levels. For, conflict is a concept that is not only investigated by management but also economy, sociology, anthropology, psychology and political sciences" (Korkmaz, 1994). The sciences in question were defined by their own fields. It is not possible to prevent conflict in organisations. Conflict means the clashes that result from the ethics, character, the family where the employees live and are raised, social environment, worldview, outlook on life, and many other psychological properties, no matter what the demographic properties of the employees working in the organisation are, such as their duty, education, age and gender (Öztekin, 2002). Conflict is a natural consequence of the interaction between individuals with different opinions. In this case, that individuals have different priorities or perceived in this way may render the formation of conflict indispensable (Thompson, 1998). In this sense, it can be said that conflict is one of the natural elements of the social environment.

Healey (1995) says that in conflicts disputants focus on limited choices and resources rather than other possibilities that may exist outside the boundaries. Therefore, a conflict is viewed usually as a negative experience.

A conflict arises from the disagreements between the people in which people see an obstacle or danger for achieving their needs, interests and concerns (Mayer, 1990). Conflicts occur naturally as people try to manage complex social circumstances in which people have personel stakes (Ury, 1988).

\footnotetext{
${ }^{1}$ This study is a further developed form of the study presented in the 15th International Classroom Teacher Training Symposium held on 11-14 May 2016 as an oral declaration.
} 
The skills to solve conflicts enable people to cooperate for restoring a fair balance for their needs. The shift from conflict to cooperation gives both parties more advantegous posibilities (Axelerood, 1984).

"Individuals spend their lives in competition. People experience certain problems in this process. These problems experienced by people are called conflicts. However, conflict with a different personal scope is explained as living in tension. Terms such as collapse, war, distemper, tension, disagreement and adverseness remind of the term of conflict" (Karip, 2010). In technical terms, they are qualified as situations in which individuals have difficulty or fail to make their preferences. If this scope is further expanded, it is qualified as a social society.

Conflict, which is colloquially named as disagreement, discrepancy, non-adaptation, generally results from certain differences between individuals and seriously damages the organisational structure. Starting from here, it is understood that conflict is "the clash between two or more organisation members or groups in the understanding of organisation both from the system and different values" (Akçakaya, 2003). Individuals, who try to fulfil their desires with the effect of multiple motives, may feel like they are unable to work it out of many options. Cüceloğlu (1991) explains this situation that is named as conflict as "it occurs when two or more motives that are incompatible affect the individual at the same time".

It is necessary to know the source and reasons for the conflicts that occur within the organisation in order to effectively manage the conflict. When organisational conflicts are examined, it is seen that most of them occur due to communication. Furthermore, works that are not well-structured and that are routine may also lead to conflict. On the other hand, organisational conflict tends to increase as the participation in decision-making increases. However, these conflicts are softer. Conflict is also about personal properties. Highly authoritarian and dogmatic personalities and personalities with low self-respect are prone to conflict.

Another reason for conflict is that the needs, drives and wishes of individuals go against one another. Certain conflicts may result from personal perception differences, or individuals may perceive this differently. These different viewpoints and different perception may also lead to conflicts (Taştan and Öner, 2010). Furthermore, there are also opinions expressing that most of the conflicts observed in organisations result not from rational reasons but emotional reasons (Başaran, 2008). "Conflict management is important for organisations as a concept. For, the lack of conflict means a monotonous structure causing boredom. The existence of conflict is expressed as a neither good nor bad situation. The dissatisfaction and nonsatiation in an organisation are effective in changing the effectiveness of the organisation as they require readdressing existing practices. The terms of conflict management and conflict resolution are different. Conflict management has a broader meaning. In conflict resolution, the conflict in question is reconciled. However, in the management of the conflict, both the reconciliation and conflict are managed in a constructive way (Çağlayan, 2006).

"Elements such as the increase in dependence, the formation of team-based structures, increase in awareness and increase in environmental uncertainties lead to an increase in the level of conflict. Studies conducted show that managers spend an important portion of their time by dealing with conflicts. That there is an optimum degree of conflict about the fight against conflict is a considerable and institutional capacity dependent situation" (Callanan and Peri, 2006). In terms of management, conflicts are important with regard to decision-making processes and they contribute to making better decisions.

"The indicator of a powerful institution culture at an institution is that the employees are in good communication with colleagues and senior staff in addition to their thinking that they are a part of that institution. Thus, they can consider the institution's interests like their interests and love and respect other colleagues like their family members. The management can achieve its objectives more quickly when there is a powerful corporate culture" (Özdemir, 2012).

As a result of the literature review made on the subject, the studies titled "Investigation of the sources of conflict that teachers experience with students in the school environment" carried out by Demir (2015), "Investigation of the development of conflict resolution skills in primary school fourth grade social sciences course" carried out by Gürdoğan Bayır (2015), "Investigation of conflict resolution approaches of high school students in terms of attachment styles and certain variables" carried out by Dede (2015), "Relationship between organisational conflict and job satisfaction relationship in pre-school teachers" carried out by Kalebaş1 (2015), "Relationship between conflict management strategies of primary school managers and organisation climate by teacher perceptions: Izmir province example" carried out by Çatakdere (2014), "Relationship between conflict management styles and negotiation skills of school managers" carried out by Yllmaz (2014), "Investigation between conflict management styles of school managers and stress levels of teachers: Istanbul province Gaziosmanpaşa district example" carried out by Atay (2014), "Investigation of the leadership behaviours and conflict management forms of primary school managers" carried out by Uzun (2014), and "Investigation of manager conflict styles perceived by the teachers working at private education institutions" carried out Gümüş Özkubat (2013) were found. However, no study examining conflict resolution skills of primary school teachers was encountered. In this context, it is thought that this study carried out in order to determine the level of conflict 
resolution skills of primary school teachers and whether they vary by different variables will contribute to the field.

This study aims to determine the level of conflict resolution skills of primary school teachers and whether they vary by different variables. The answers to the following questions were sought in line with this general aim.

1. What is the level of conflict resolution skills of primary school teachers?

2. Do the conflict resolution skills of primary school teachers vary by marital status, gender, and age?

\section{Method}

\subsection{Model of the Research}

The study was organised in accordance with the scanning model. Karasar (2002) defines survey models as research approaches that aim to describe the past or current situation as it is.

\subsection{Population and Sample}

The population of the study consists of primary school teachers working at 14 primary schools, two from each of the seven geographical regions. The sample group consists of 191 primary school teachers that were randomly selected from schools that make up the population.

\subsection{Data Collection Tools and Techniques}

The "Conflict Resolution Skills" scale that was developed by Rahim in order to determine conflict resolution skills and adapted into Turkish by Gümüşeli (2001) was used in this study. The reliability studies of the conflict resolution skills scale used within the scope of the study were previously conducted by Rahim, and the reliability of the scale (Cronbach's Alpha values) was found to be 0.73 . According to the criteria that are complied with in the assessment of the Alpha coefficient, these data show that the survey is reliable. That the questions that make up the scale are gathered under reconciliating, integrating, avoiding, dominating and compromising factors as a result of the factor analysis applied to the scale by Rahim and Gümüşeli was stated by authors in their relevant studies.

In the reconciliation approach where it is possible to partially give up and partially gain, the parties neither fully protect their positions nor fully lose them. The parties try to make an acceptable decision (no winner-no loser) by making concessions (Edmonson, Combs \& Haris, 2008; Ghaffar, 2010; Rahim, Antonioni \& Psenicka, 2001).

In the integration approach, the parties participate in the solution in cooperation, and they do not experience the worry of the fact that they will be eventually neglected. The parties show an effort to mutually maximise their benefit (Zikmann, 1992). In this approach, the level that the individual heads for both one's own and the other party's interests and needs is high (Rahim, Antonioni \& Psenicka, 2001).

In the avoidance approach, the conflict situation is ignored and neglected. Rahim, Antonioni \& Psenicka (2001) state that the interests and needs of conflicting parties are ignored, and there is a consequence in which both parties lose (lose-lose) in the avoiding style. Ignoring the conflict may lead to hidden hostility and insecurity by causing an increase in the tension of the organisation.

The dominating approach is a conflict resolution strategy, in which one of the conflicting parties wins and the other loses (win-lose) (Rahim, Antonioni \& Psenicka, 2001). In the dominating strategy, while it seems like a party wins in a short time and the problem is solved, the sense of losing and "unfinished works" in losing party/parties may affect personal and corporate dynamics in the long term.

The concession strategy is the opposite of dominating, and it means that one of the parties loses as a result of making concessions on its needs and consequently ensures that the other party wins (lose-win) (Rahim, Antonioni \& Psenicka, 2001). Making concession may cause that conflict results in an unwanted manner and the components create an incorrect solution. Nevertheless, many managers state that making a concession is the most suitable method for the parties (Zikmann, 1992).

The survey is prepared in 5-item Likert scale, and it includes the expressions, D1: "Totally disagree", D2: "Disagree.", D3: "Neither agree nor disagree.", D4: "Agree", and D5: "Totally agree." While the answer "Totally Disagree" is represented with the number (1), the answer "Totally Agree" is represented with the number five (5). The following assessment table is found when we proceed in the light of the formula $(n-1 / n)$ that will form the scale that represents this range equally. 
Table 1. Scale Arithmetic Mean Distribution

\begin{tabular}{lllll}
\hline $\begin{array}{l}\text { Totally } \\
\text { Disagree }\end{array}$ & Disagree & $\begin{array}{l}\text { Neither Agree } \\
\text { Nor Disagree }\end{array}$ & Agree & Totally Agree \\
\hline Very Low & Low & Medium & High & Very High \\
$1 \leq \bar{x}<1,80$ & $1,81 \leq \bar{x}<2,60$ & $2,61 \leq \bar{x}<3,40$ & $3,41 \leq \bar{x}<4,20$ & $4,21 \leq \bar{x}<5$ \\
\hline
\end{tabular}

With the help of this rating, it is assessed that the mean of the answers given will help reveal the stress-coping levels of the participants of the survey. The teachers who were believed to represent the universe and made up the sample were chosen randomly for the research, and the scales were implemented. It was tried to ensure that the scales were replied sincerely considering the principle of voluntariness. It was also aimed to ensure the trust of the teachers by declaring that the results would not be given to anyone in line with the principle of privacy that the scale results would be used for the research.

At the stage of the data analysis; frequency, percentage, arithmetic mean and standard deviation data were used by the state of need in the analysis of the data using the statistics software, while ANOVA test and independent tests were used in order to reveal the difference and significant relation between the factors and personal traits. When the reliability values formed in accordance with the answers given to the scale that had been applied were examined before including the findings found as a result of the analyses, the alpha value of the Conflict Resolution Skills scale was found as 0,818 .

\section{Findings}

The tables showing the ANOVA test and independent sample t-test results together with the factor based frequency distribution, arithmetic mean and standard deviations of conflict resolution scale applied within the scope of the study are as follows.

Table 2. Conflict Resolution Levels of the Students

\begin{tabular}{llllll}
\hline $\begin{array}{l}\text { Row } \\
\text { No }\end{array}$ & $\begin{array}{l}\text { Factor } \\
\text { Code }\end{array}$ & Factor (Approach) & $\begin{array}{l}\text { Number of } \\
\text { Questions }\end{array}$ & $\begin{array}{l}\text { Participants } \\
\text { (n) }\end{array}$ & $\bar{x}$ \\
\hline 1 & DA & Dominating approach & 5 & 191 & 2,81 \\
2 & AA & Avodiance aproach & 6 & 191 & 3,36 \\
3 & CA & Concession approach & 5 & 191 & 3,15 \\
4 & IA & Integration approach & 6 & 191 & $\mathbf{4 , 0 2}$ \\
5 & RA & Reconciliation approach & 6 & 191 & 3,73 \\
\hline \multicolumn{2}{r}{ TOTAL } & & $\mathbf{2 8}$ & $\mathbf{1 9 1}$ & $\mathbf{3 , 4 1}$ \\
\hline
\end{tabular}

Table 2 contains the distribution formed in line with the results given by primary school teachers in the sample group to conflict resolution skills. The scale consists of five factors in total being dominating, avoiding, making a concession, integrating and reconciliation. When the scale was assessed as a whole, it was determined that the conflict resolution skills of primary school teachers are at intermediate level $(\bar{x}=3,41)$. Upon examining the frequency distributions, it is seen that primary school teachers generally prefer the Integrating Approach as a way of conflict resolution (with $\bar{x}=4,02)$.

Table 3. ANOVA Test Results Showing the Difference between the Marital Status and Conflict Resolution Skills of the Teachers

\begin{tabular}{|c|c|c|c|c|c|c|}
\hline Factors & & K.T. & S.D. & K.O. & $\mathbf{F}$ & $\mathbf{P}$ \\
\hline \multirow{4}{*}{ Dominating approach } & Intergroup & ,071 & 1 & ,071 & ,201 & 655 \\
\hline & Intragroup & 66,444 & 189 & ,352 & & \\
\hline & Total & 66,515 & 190 & & & \\
\hline & Intergroup & 000 & 1 & ,000 & ,001 & ,982 \\
\hline \multirow[t]{3}{*}{ Avoidance approach } & Intragroup & 74,089 & 189 & 392 & & \\
\hline & Total & 74,089 & 190 & & & \\
\hline & Intergroup & 053 & 1 & 053 & ,211 & ,646 \\
\hline \multirow[t]{3}{*}{ Concession approach } & Intragroup & 47,243 & 189 & 250 & & \\
\hline & Total & 47,296 & 190 & & & \\
\hline & Intergroup & 201 & 1 & 201 & ,913 & 340 \\
\hline \multirow[t]{3}{*}{ Integration approach } & Intragroup & 41,554 & 189 & 220 & & \\
\hline & Total & 41,755 & 190 & & & \\
\hline & Intergroup & 010 & 1 &, 010 & 053 & ,819 \\
\hline \multirow[t]{2}{*}{ Reconciliation approach } & Intragroup & 36,674 & 189 & 194 & & \\
\hline & Toplam & 36,685 & 190 & & & \\
\hline
\end{tabular}

In Table 3, whether there is a difference between the marital status and conflict resolution skills of primary school teachers in the sample group was shown with the ANOVA test. Upon examining the results, it is seen that the 
approaches in the scale do not vary significantly by the marital status of primary school teachers.

Table 4. ANOVA Test Results Showing the Difference between the Gender and Conflict Resolution Skills of the Teachers

\begin{tabular}{|c|c|c|c|c|c|c|}
\hline Factors & & K.T. & S.D. & K.O. & $\mathbf{F}$ & $\mathbf{P}$ \\
\hline \multirow{3}{*}{ Dominating approach } & Intergroup & ,014 & 1 & ,014 & ,040 & 841 \\
\hline & Intragroup & 66,501 & 189 &, 352 & & \\
\hline & Total & 66,515 & 190 & & & \\
\hline \multirow{3}{*}{ Avoidance approach } & Intergroup &, 148 & 1 & , 148 & ,379 &, 539 \\
\hline & Intragroup & 73,941 & 189 & ,391 & & \\
\hline & Total & 74,089 & 190 & & & \\
\hline \multirow{3}{*}{ Concession approach } & Intergroup & ,093 & 1 & ,093 & ,374 &, 542 \\
\hline & Intragroup & 47,203 & 189 & 250 & & \\
\hline & Total & 47,296 & 190 & & & \\
\hline \multirow{3}{*}{ Integration approach } & Intergroup & 002 & 1 & ,002 & 011 & ,918 \\
\hline & Intragroup & 41,753 & 189 & ,221 & & \\
\hline & Total & 41,755 & 190 & & & \\
\hline \multirow{3}{*}{ Reconciliation approach } & Intergroup & 344 & 1 & .344 & 1.791 & .182 \\
\hline & Intragroup & 36,340 & 189 & , 192 & & \\
\hline & Total & 36,685 & 190 & & & \\
\hline
\end{tabular}

In Table 4, whether there is a difference between the gender of primary school teachers in the sample group and their conflict resolution skills was revealed with the ANOVA test. Upon examining the results, it is seen that the approaches in the scale do not vary significantly by the gender of primary school teachers.

Table 5. ANOVA Test Results Showing the Difference between the Age Groups and Conflict Resolution Skills of the Teachers

\begin{tabular}{|c|c|c|c|c|c|c|}
\hline Factors & & K.T. & S.D. & K.O. & $\mathbf{F}$ & $\mathbf{P}$ \\
\hline & Intergroup & ,720 & 4 & 180 & 509 & ,729 \\
\hline \multirow[t]{2}{*}{ Dominating approach } & Intragroup & 65,795 & 186 &, 354 & & \\
\hline & Total & 66,515 & 190 & & & \\
\hline \multirow{4}{*}{ Avoidance approach } & Intergroup & 1,342 & 4 & ,336 & ,858 & ,490 \\
\hline & Intragroup & 72,747 & 186 & ,391 & & \\
\hline & Total & 74,089 & 190 & & & \\
\hline & Intergroup & 3,687 & 4 & ,922 & 3,931 & ,004 \\
\hline \multirow[t]{3}{*}{ Concession approach } & Intragroup & 43,609 & 186 & ,234 & & \\
\hline & Total & 47,296 & 190 & & & \\
\hline & Intergroup & 2,085 & 4 &, 521 & 2,444 &, 052 \\
\hline \multirow[t]{3}{*}{ Integration approach } & Intragroup & 39,670 & 186 & ,213 & & \\
\hline & Total & 41,755 & 190 & & & \\
\hline & Intergroup & 1,202 & 4 & ,301 & 1,576 & 183 \\
\hline \multirow[t]{2}{*}{ Reconciliation approach } & Intragroup & 35,482 & 186 &, 191 & & \\
\hline & Total & 36,685 & 190 & & & \\
\hline
\end{tabular}

In Table 5, whether there is a difference between the age groups of the primary school teachers in the sample group was shown with the ANOVA test. Upon examining the results, it is seen that the approaches apart from the concession approach do not vary significantly by age groups. As $\mathrm{P}$ value is $0,004<0,05$ in the concession approach, a significant difference is found between the age groups of primary school teachers and making concession approach.

Table 6. Results of Descriptive Statistics of the Answers Given by Teachers to Making Concession Approach by Age Groups

\begin{tabular}{|c|c|c|c|c|c|c|c|c|c|}
\hline \multicolumn{2}{|c|}{ Age Group } & $\mathbf{N}$ & $\bar{x}$ & S.D. & S.E. & \multicolumn{2}{|c|}{$\begin{array}{l}\text { 95\% Confidence Interval for the Average } \\
\text { Lower Level } \\
\end{array}$} & Min & Max \\
\hline \multirow{6}{*}{ Concession } & $22-27$ & 55 & 3,1200 & ,43136 & ,05816 & 3,0034 & 3,2366 & 2,00 & 4,20 \\
\hline & $28-33$ & 71 & 3,0169 & ,43654 & ,05181 & 2,9136 & 3,1202 & 1,20 & 4,00 \\
\hline & 34-39 & 42 & 3,3714 &, $\mathbf{5 8 5 3 0}$ & ,09031 & 3,1890 & 3,5538 & 2,20 & 4,40 \\
\hline & $40-45$ & 9 & 3,1778 & ,36667 & , 12222 & 2,8959 & 3,4596 & 2,60 & 3,60 \\
\hline & 46 ve üzeri & 14 & 3,3000 & 62634 & , 16740 & 2,9384 & 3,6616 & 2,60 & 4,60 \\
\hline & Toplam & 191 & 3,1529 &, 49892 &, 03610 & $\mathbf{3 , 0 8 1 7}$ & 3,2241 & 1,20 & 4,60 \\
\hline
\end{tabular}

Upon examining the ANOVA test statistical distribution shown in Figure 6, it is seen that primary school teachers working at the age interval between 34 and 39 prefer making concession approach more than other age groups. 
Table 7. ANOVA Test Results Showing the Difference between the Education Status and Conflict Resolution Skills of the Teachers

\begin{tabular}{|c|c|c|c|c|c|c|}
\hline Factors & & K.T. & S.D. & K.O. & $\mathbf{F}$ & $\mathbf{P}$ \\
\hline \multirow{3}{*}{ Dominating approach } & Intergroup &, 118 & 1 & ,118 & ,336 & ,563 \\
\hline & Intragroup & 66,397 & 189 & 351 & & \\
\hline & Total & 66,515 & 190 & & & \\
\hline \multirow{3}{*}{ Avoidance approach } & Intergroup &, 507 & 1 & ,507 & 1,303 & ,255 \\
\hline & Intragroup & 73,582 & 189 & ,389 & & \\
\hline & Total & 74,089 & 190 & & & \\
\hline \multirow{3}{*}{ Concession approach } & Intergroup &, 036 & 1 & ,036 &, 144 & ,705 \\
\hline & Intragroup & 47,260 & 189 & 250 & & \\
\hline & Total & 47,296 & 190 & & & \\
\hline \multirow{3}{*}{ Integration approach } & Intergroup &, 316 & 1 & ,316 & 1,443 & ,231 \\
\hline & Intragroup & 41,439 & 189 & 219 & & \\
\hline & Total & 41,755 & 190 & & & \\
\hline \multirow{3}{*}{ Reconciliation approach } & Intergroup & 019 & 1 & 019 & 099 & ,753 \\
\hline & Intragroup & 36,665 & 189 &, 194 & & \\
\hline & Total & 36,685 & 190 & & & \\
\hline
\end{tabular}

In Table 7, whether there is a difference between the education status and conflict resolution skills of primary school teachers in the sample group was revealed using the ANOVA test. Upon examining the results, it is seen that the approaches in the scale do not show a significant difference by the education status of primary school teachers.

Table 8. ANOVA Test Results Showing the Difference between the Years of Service and Conflict Resolution Skills of the Teachers

\begin{tabular}{|c|c|c|c|c|c|c|}
\hline Factors & & K.T. & S.D. & K.O. & $\mathbf{F}$ & $\mathbf{P}$ \\
\hline \multirow{4}{*}{ Dominating approach } & Intergroup & 1,530 & 4 &, 383 & 1,095 & 360 \\
\hline & Intragroup & 64,985 & 186 & ,349 & & \\
\hline & Total & 66,515 & 190 & & & \\
\hline & Intergroup & 4,504 & 4 & 1,126 & 3,010 & ,062 \\
\hline \multirow[t]{3}{*}{ Avoidance approach } & Intragroup & 69,585 & 186 & ,374 & & \\
\hline & Total & 74,089 & 190 & & & \\
\hline & Intergroup & 3,402 & 4 & 850 & 3,604 & ,007 \\
\hline \multirow[t]{3}{*}{ Concession approach } & Intragroup & 43,894 & 186 & ,236 & & \\
\hline & Total & 47,296 & 190 & & & \\
\hline & Intergroup & 1,164 & 4 & 291 & 1,333 & ,259 \\
\hline \multirow[t]{3}{*}{ Integration approach } & Intragroup & 40,591 & 186 & ,218 & & \\
\hline & Total & 41,755 & 190 & & & \\
\hline & Intergroup & 1,242 & 4 & ,311 & 1,630 & ,168 \\
\hline \multirow[t]{2}{*}{ Reconciliation approach } & Intragroup & 35,442 & 186 &, 191 & & \\
\hline & Total & 36,685 & 190 & & & \\
\hline
\end{tabular}

In Table 8, whether there is a difference between the years of service and conflict resolution skills of primary school teachers in the sample group was shown with the ANOVA test. Upon examining the results, it is seen that the approaches other than making concession approach do not exhibit significant difference by the years of service. However, there is a significant difference between the years of service of primary school teachers and making concession approach as $\mathrm{P}$ value is $0,007<0,05$ in making concession approach.

Table 9. Descriptive Statistics Results of the Answers Given by Teachers to Making Concession Approach by Their Years of Service

\begin{tabular}{|c|c|c|c|c|c|c|c|c|c|}
\hline & $\begin{array}{l}\text { Period of } \\
\text { Service }\end{array}$ & $\mathbf{N}$ & $\bar{x}$ & S.D. & S.E. & $\begin{array}{l}\text { 95\% Confiden } \\
\text { Lower Limit }\end{array}$ & $\begin{array}{l}\text { rval for the Average } \\
\text { Upper Limit }\end{array}$ & Min & Max \\
\hline \multirow{6}{*}{ Concession } & $0-5$ & 81 & 3,3519 & ,54327 & ,06036 & 3,2317 & 3,4720 & 2,00 & 4,33 \\
\hline & $6-10$ & 52 & 3,2308 & ,64857 & ,08994 & 3,0502 & 3,4113 & 1,67 & 4,00 \\
\hline & $11-15$ & 34 & 3,4608 & ,70000 & , 12005 & 3,2165 & 3,7050 & 1,67 & 4,83 \\
\hline & $16-20$ & 19 & 3,4035 & ,57819 & 13265 & 3,1248 & 3,6822 & 2,67 & 4,67 \\
\hline & 21 ve üzeri & 5 & 4,1667 & ,76376 & ,34157 & 3,2183 & 5,1150 & $\mathbf{3 , 5 0}$ & $\mathbf{5 , 0 0}$ \\
\hline & Toplam & 191 & 3,3647 & ,62445 & ,04518 & 3,2756 & 3,4539 & 1,67 & 5,00 \\
\hline
\end{tabular}

Upon examining the statistical distribution of the ANOVA test shown in Table-9, it is seen that primary school teachers with the service of 21 years and above prefer making concession approach more than those with other years of service. 
Table 10. ANOVA Test Results Showing the Difference between the Geographical Regions where Teachers Work and Their Conflict Resolution Skills

\begin{tabular}{|c|c|c|c|c|c|c|}
\hline Factors & & K.T. & S.D. & K.O. & $\mathbf{F}$ & $\mathbf{P}$ \\
\hline & Intergroup & 1,382 & 6 & .230 & ,651 & ,689 \\
\hline \multirow[t]{3}{*}{ Dominating approach } & Intragroup & 65,133 & 184 & 354 & & \\
\hline & Total & 66,515 & 190 & & & \\
\hline & Intergroup & 4,436 & 6 & ,739 & 1,953 & ,075 \\
\hline \multirow[t]{3}{*}{ Avoidance approach } & Intragroup & 69,653 & 184 & 379 & & \\
\hline & Total & 74,089 & 190 & & & \\
\hline & Intergroup & 2,485 & 6 & ,414 & 1,700 &, 123 \\
\hline \multirow[t]{3}{*}{ Concession approach } & Intragroup & 44,811 & 184 & 244 & & \\
\hline & Total & 47,296 & 190 & & & \\
\hline & Intergroup & 1,616 & 6 & ,269 & 1,235 & ,290 \\
\hline \multirow[t]{3}{*}{ Integration approach } & Intragroup & 40,139 & 184 & 218 & & \\
\hline & Total & 41,755 & 190 & & & \\
\hline & Intergroup & 1,687 & 6 & ,281 & 1,478 &, 188 \\
\hline \multirow[t]{2}{*}{ Reconciliation approach } & Intragroup & 34,998 & 184 & 190 & & \\
\hline & Total & 36,685 & 190 & & & \\
\hline
\end{tabular}

In Table 10, whether there is a difference between the geographical regions and conflict resolution skills of the primary school teachers in the sample group is shown with the ANOVA test. Upon examining the results, it is seen that the approaches in the scale do not exhibit significant difference by the geographical regions where primary school teachers work.

Table 11. ANOVA Test Results Showing the Difference between the Provinces where Teachers Work and Their Conflict Resolution Skills

\begin{tabular}{|c|c|c|c|c|c|c|}
\hline Factors & & K.T. & S.D. & K.O. & $\mathbf{F}$ & $\mathbf{P}$ \\
\hline & Intergroup & 4,481 & 13 & ,345 & ,984 & 469 \\
\hline \multirow[t]{3}{*}{ Dominating approach } & Intragroup & 62,034 & 177 & ,350 & & \\
\hline & Total & 66,515 & 190 & & & \\
\hline & Intergroup & 6,213 & 13 & ,478 & 1,246 &, 250 \\
\hline \multirow[t]{3}{*}{ Avoidance approach } & Intragroup & 67,877 & 177 &, 383 & & \\
\hline & Total & 74,089 & 190 & & & \\
\hline & Intergroup & 2,636 & 13 & ,203 & ,804 & ,656 \\
\hline \multirow[t]{3}{*}{ Concession approach } & Intragroup & 44,660 & 177 & 252 & & \\
\hline & Total & 47,296 & 190 & & & \\
\hline & Intergroup & 2,479 & 13 & ,191 &, 859 &, 597 \\
\hline \multirow[t]{3}{*}{ Integration approach } & Intragroup & 39,276 & 177 & 222 & & \\
\hline & Total & 41,755 & 190 & & & \\
\hline & Intergroup & 3,236 & 13 & 249 & 1,317 & ,206 \\
\hline \multirow[t]{2}{*}{ Reconciliation approach } & Intragroup & 33,449 & 177 & 189 & & \\
\hline & Total & 36,685 & 190 & & & \\
\hline
\end{tabular}

In Table11, whether there is a difference between the provinces where primary school teachers work in sample group and their conflict resolution skills is shown with the ANOVA test. Upon examining the results, it is seen that the approaches in the scale do not show a significant difference by the provinces where primary school teachers work.

\section{Consequence, Discussion and Suggestions}

In the light of the data and findings obtained from the studies made on the subject; the analysis results concerning the research were addressed at different dimensions and presented below.

It was determined that the conflict resolution skills of primary school teachers are at the medium level. It is seen that primary school teachers generally prefer the Integrating Approach as a conflict resolution style.

Upon examining the relationship between the conflict resolution skills and demographic properties of primary school teachers, a significant difference was found between the independent variables of age and years of service and making concession approach. It was concluded that teachers at the age interval between 34 and 39 tend to use making concession approach more than teachers at other age groups, and teachers with 21 and more years of service tend to use it more than teachers working at other years of service.

Conflict resolution skills of primary school teachers do not show a significant difference by the variables of marital status, gender, education status, and the geographical region and province where they work.

When the literature review was performed on the subject of the study, various studies that address the relationship between the conflict resolution methods that constitute the basis of the research and demographic variables together were found. 
The studies that are similar to and different from the results of this study are as follows:

Gökalp (2013), who examined stress-coping and conflict resolution methods, it was observed that there is a weak positive relationship between the reconciliation approach and seeking social support approach, avoiding approach and desperateness and submissive approach, and reconciliation approach and seeking social support and optimistic approach.

Karcioğlu et al. (2011) determined that both the managers and their subordinates prefer the integrating approach as the conflict resolution approach. This determination is in parallel with our study, and it is found that managers and teachers mostly consult the integrating approach within the scope of this study.

In the study that examines the management style of interpersonal conflicts between school managers and teachers, Atakan (2014) detected that managers use the integrating approach most and dominating approach least in the cases of conflict; and showed that the situation of using the avoiding approach when compared to the gender variable, and men prefer the avoiding approach more than women, however, other approaches are independent of the gender variable.

Koçak (2012) observed that teachers prefer the integrating and adaptation approaches more in the conflicts between the managers and teachers, while teachers prefer avoiding and dominating approaches more in the conflict atmospheres between each other. Nevertheless, the reconciliation method is generally used at a high level in all conflict situations and brings about a high level of the solution.

In the study on determining whether the conflict resolution styles of teachers working at vocational high schools in the school environment vary by demographic properties, Özer (2014) determined that teachers use the integrating style at the first place, reconciliation at the second place, submission at the third place, avoiding at the fourth place, and dominating at the last place.

According to the result of the study conducted by Tan (2016), the most frequently used style by school managers while managing and resolving the conflict is the integrating style. The integrating style is followed by reconciliation, making a concession, avoiding and dominating styles. The preferences of school managers by management styles do not vary significantly by demographic variables.

As a result of the study carried out by Batmaz (2015), it was determined that the managers of sports high schools effectively use their behaviour styles during the conflict and have high skills of using resolution strategies against conflicts. However, it was determined that as the professional and managerial experience of managers decreases, their skills of using behaviour styles and solution strategies against conflicts also decrease.

The result of the study conducted by Şahin (2016) shows that managers use the problem-solving strategy most and reconciliation strategy least in the process of conflict management. It is seen that the opinions on the use of humour in the process of conflict are generally positive. It was seen that there is generally a significant relationship between the humour climate of primary education institutions, humour styles of the managers and conflict management strategies. It was found that humour styles of the managers are an important predictor of the humour climate of the schools and conflict management strategies of the managers.

As a result of the study conducted by Aydın (2015), it was seen that the differences in perceiving the behaviours are considered as the most significant reason for conflict, while the size of the organisation was considered as the least significant reason for conflict according to the opinions of teachers and managers. Reconciliation was indicated as the most used conflict resolution, and the change of place of the parties of the conflict was expressed as the least used conflict resolution. There is no significant difference between the reason and resolution scores of the conflicts that occur at school by the gender, marital status, subject matter and years of working at the school of the teachers and managers working at the primary school. There is a significant difference between the reason of conflict scores at school by the age, school type and experience of the teachers and managers working at the primary school, and the resolution of conflict scores at school by the type of duty.

As a result of the study conducted by Çakı (2015), it was found that "Communication" is the primary reason for conflict between educators, and this is followed by the problems under the sub-titles "the way of doing something", "management and privilege", "attitude". While the "cooperation" style is used most in the management styles of the educators, this style was followed by "reconciliation", "avoiding", "submission" and "dominating" styles.

As a result of the study conducted by Karataş (2015), it was found that there are significant differences between the attitudes of school managers towards conflict by gender, however, there is no significant difference between conflict management strategies used by school managers by gender. On the other hand, it was found that social and organisational stereotypes are effective on the approaches of school managers towards conflicts by gender.

The following suggestions are mentioned in line with the findings of the research: 
Knowing the path to follow in order to eliminate the negative aspects of the conflict that dominate in addition to its positive effects is important for teachers, who are important elements of education institutions. In this framework, holding awareness-raising training and seminars by the directorates of national education will be a significant step in increasing situational awareness.

As is also shown by research results, it should be noted that the way to get maximum yield from integrating and reconciliating approaches among conflict resolution methods is communication, and any kind of social communication should be increased in education institutions, and it should also be noted that paving the way for socialisation to the extent that bureaucratic arrangements allow will enable the creation of more serene environments. Open door policies adopted by managers are quite important as they will allow teachers to contact their managers in the slightest confusion.

In this study, classroom teachers were investigated as the sample group. Similar studies may be applied to a different sample group. They can be applied by extending the sample group. The conflict resolution skills of preservice teachers and teachers may be compared by different variables.

\section{References}

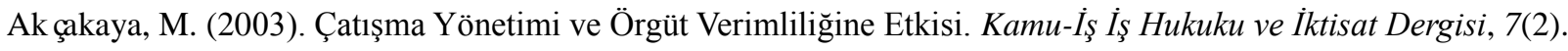

Alexelrod, R. M. (1984). The evolution of cooperation. New York: Basic Books.

Atakan, S. H. (2014). Okul Yöneticilerinin Öğretmenlerle Yaşadıkları Bireylerarası Çatışmaları Yönetme Stillerinin Incelenmesi. Yayınlanmamış yüksek lisans tezi, Sabahattin Zaim Üniversitesi, İstanbul.

Atay, A. (2014). Okul Yöneticilerinin Çatışma Yönetimi Stillerinin Öğretmenlerin Stres Düzeyleriyle İlişkisinin Incelenmesi: Ístanbul İli Gaziosmanpaşa İlçesi Örneği. Yüksek lisans tezi, İstanbul Aydın Üniversitesi, İstanbul.

Aydın, B. (2015). İlkokullarda Görevli Öğretmenler ve Yöneticilerin Okullarda Yaşanan Çatışma Nedenleri ve Çözümlerine İlişkin Görüşleri (Karşıyaka Örneği). Yüksek lisans tezi, Okan Üniversitesi, İstanbul.

Başaran, İ. (2008). Örgütsel Davranış Insanın Üretim Gücü. Ankara: Ekinoks Yayınları.

Batmaz, H. Ç. (2015). Spor Liseleri Yöneticilerinin Çatışmaları Yönetme Becerileri Üzerine Bir Araştırma. Yüksek lisans tezi, Firat Üniversitesi, Elazı̆̆.

Çağlayan, O. A. (2006). Örgütsel Çatışma Yönetimi ve Bir Araştırma. Yayımlanmamış yüksek lisans tezi. Pamukkale Üniversitesi: Denizli.

Çakı, R. (2015). Öğreticilerin ve Yöneticilerin Çatışmayı Yönetme Becerileri. Yüksek lisans tezi, Yeditepe Üniversitesi, İstanbul.

Callanan, G., \& Peri, D. (2006). Teaching Conflict Management Using a Scenario-Based Approach. Journal of Education for Business, 81(3). http://dx.doi.org/10.3200/JOEB.81.3.131-139

Çatakdere, K. (2014). Öğretmen Algılarına Göre İlköğretim Kurumları Yöneticilerinin Çatışma Yönetimi Stratejileri ile Örgüt İklimi Arasındaki İlişki: İzmir İli Örneği. Yüksek lisans tezi, Okan Üniversitesi, İstanbul.

Cüceloğlu, D. (1991). İnsan ve Davranışı. Remzi Kitabevi Yayınları, İstanbul.

Dede, F. (2015). Lise Öğrencilerinin Çatışma Çözme Yaklaşımlarının Bağlanma Stilleri ve Bazı Değişkenler Açısından Incelenmesi. Yüksek lisans tezi, Çukurova Üniversitesi, Adana.

Demir, P. (2015). Öğretmenlerin Okul Ortamında Öğrencilerle Yaşadı̆̆ı Çatışma Kaynaklarının İncelenmesi. Yüksek lisans tezi, Okan Üniversitesi, İstanbul.

Edmonson, S., Combs, J., \& Hariss, S. (2008). Managing Conflict: 50 Strategies For School Leaders. San Antonio: Eye on Education.

Ghaffar, A. (2010). Conflict in Schools: Its Causes \& Management Strategies. Journal of Managerial Sciences, $3(2), 212-227$.

Gökalp, S. (2013). Lisansüstü Hemşirelik Öğrencilerinin Stresle Başa Çıkma Tarzları, Psikolojik Güçlendirme ve Çatışma Yönetimi Stilleri. Yayımlanmış yüksek lisans tezi, Haliç Üniversitesi, İstanbul.

Gümüş, Ö. İ. (2013). Özel Eğitim Okullarında Görev Yapan Öğretmenlerin Algıladıkları Yönetici Çatışma Stillerinin Incelenmesi. Yüksek lisans tezi, Yeditepe Üniversitesi, İstanbul.

Gümüşeli, A. İ. (2001). İlköğretim Okulu Müdürlerinin Çatışma Yönetimi Stilleri ile Öğretmenlerin İş Doyumu Arasındaki İlişki. Yayımlanmamış Araştırma. İstanbul.

Gürdoğan, B. Ö. (2015). İlkokul Dördüncü Sınıf Sosyal Bilgiler Dersinde Çatışma Çözme Becerilerinin Gelişiminin Incelenmesi. Doktora tezi, Anadolu Üniversitesi, Eskişehir. 
Healey, K. (1995). Conflict Resolution. Balmain: Spinney Press.

Kalebaşı, E. S. (2015). Anaokulu Öğretmenlerinde Örgütsel Çatışma ve İş Doyumu İlişkisi. Yüksek lisans tezi, İstanbul Aydın Üniversitesi, İstanbul.

Karasar, N. (2002). Bilimsel Araştırma Yöntemleri. Ankara: Nobel Yayınları.

Karataş, E. (2015). Cinsiyete Göre Okul Yöneticilerinin Çatışma Nedenleri ve Çatışma Yönetimi Stratejileri (Keşan Örneği). Yüksek lisans tezi, Çanakkale Onsekiz Mart Üniversitesi, Çanakkale.

Karcığlu, F., Gövez, E., \& Kahya, C. (2011). Yöneticilerin İletişim Tarzı ve Kullandıkları Çatışma Yönetim Stili Arasındaki İlişki. Atatürk Üniversitesi Sosyal Bilimler Enstitüsü Dergisi, 15(1), 327-340.

Karip, E. (2010). Çatışma Yönetimi. Ankara: Pegem Yayıncılık.

Koçak, S. (2012). Öğretmenler Arası Çatışmalar ile Okul Müdürü - Öğretmen Çatışmalarında Kullanılan Yöntemlerin ve Etkilik Düzeylerinin Karşılaştırılması Uşak Illi Örneği. Yüksek lisans tezi, Hacettepe Üniversitesi Eğitim Bilimler Enstitüsü, Ankara.

Korkmaz, S. (1994). Örgütlerde Çatışma Yönetimi ve Verimlilik. Verimlilik Dergisi, 1, 77-94.

Mayer, R. J. (1990). Conflict management: the courage to confront. Columbus, Ohio: Battelle Press.

Özdemir, A. (2012). Çatışma ve Stres Yönetimi-I. Eskişehir: Anadolu Üniversitesi Yayını.

Özer, İ. (2014). Okullarda Öğretmenlerin Yaşadı̆̆ Çatışma ve Çatışma Yönetim Stilleri. Yüksek lisans tezi, Bahçeşehir Üniversitesi, İstanbul.

Öztekin, A. (2002). Yönetim Bilimi. Ankara: Siyasal Kitabevi.

Rahim, A., Antonioni, D., \& Psenicka, C. (2001). A Structural Equations Model of Leader Power, Subordinates' Styles of Handling Conflict and Job Performance. The International Journal of Conflict Management, 3(2), $191-211$. http://dx.doi.org/10.1108/eb022855

Şahin, A. (2016). İlköğretim Kurumu Yöneticilerinin Yönetsel İlişkilerinde Kullandıkları Mizaha İlişkin Görüşler ile Mizah İklimi, Yöneticilerin Mizah Tarzları ve Çatışma Yönetimi Stratejileri Arasındaki İlişki. Doktora tezi, Akdeniz Üniversitesi, Antalya.

Tan, G. (2016). Okul Yöneticilerinin Çatışma Yönetme Stilleri ve Problem Çözme Becerileri Arasındaki İlişki. Yüksek lisans tezi, Yeditepe Üniversitesi, İstanbul.

Taştan, N., \& Öner, U. (2010). Çatışma Çözme Ĕ̆itimi ve Akran Arabuluculuğu. Ankara: Nobel Yayın Dağıtım.

Thompson, B. (1998). Yeni Yöneticinin El Kitabl-2:Üstün Performans Geliştirme. İstanbul: Hayat Yayınları.

Ury, W. (1988). Getting disputes resolved: Designing systems to cut the costs of conflict. Calif: Jossey-Bass

Uzun, S. (2014). İlkokul Yöneticilerinin Liderlik Davranışları ile Çatışma Yönetim Biçimlerinin İncelenmesi. Yüksek lisans tezi, Okan Üniversitesi, İstanbul.

Yılmaz, S. (2014). Okul Yöneticilerinin Çatışmayı Yönetme Stilleri ile Müzakere Becerileri Arasındaki İlişki. Yüksek lisans tezi, Harran Üniversitesi, Şanlıurfa.

Zikmann, R. (1992). Successful Conflict Management: Construction Conflict Management and Resolution: Proceedings of The First. London: Chapman \& Hall.

This work is licensed under a Creative Commons Attribution 3.0 License. 